Journal of Materials and Environmental Sciences ISSN : 2028-2508

CODEN : JMESCN

Copyright $\odot 2017$

University of Mohammed Premier Oujda Morocco
J. Mater. Environ. Sci., 2018, Volume 9, Issue 1, Page 113-118

https://doi.org/10.26872/jmes.2018.9.1.14

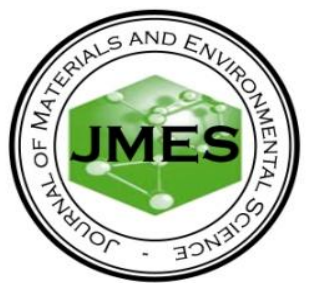

\title{
Chemical characterization, antioxidant and antibacterial activity of Moroccan Crocus sativus $L$ petals and leaves
}

\author{
S.M. Jadouali ${ }^{1,2}$, H. Atifi ${ }^{1,2}$, Z. Bouzoubaa ${ }^{1}$, K. Majourhat ${ }^{2}$, S. Gharby ${ }^{2}$ \\ F. Achemchem ${ }^{2,3}$, A. Elmoslih ${ }^{3}$, A. Laknifli ${ }^{2}$, R. Mamouni ${ }^{2}$ \\ 1. Research Unit Natural Resources and Terroirs Products UR RN\&PDT-INRA-CRRA-Agadir ;
}

2. Catalysis Materials Team and Natural Resource Development, Faculty of Science, University Ibn Zohr, Agadir, Morocco

3. Laboratory Biotechnology and Natural Resources Valorization, Faculty of Science, University Ibn Zohr, Agadir, Morocco

Received 25 May 2017,

Revised 05 Aug 2017,

Accepted 13 Aug 2017

Keywords

$\checkmark$ Phytochemical screening;

$\checkmark$ Dpph;

$\checkmark$ frap;

$\checkmark$ antibacterial activity

jadonalisimohamed@gmail.com Phone: +212659859841

\begin{abstract}
The phytochemical, antioxidant and mineral composition of petals and leaves of Moroccan Crocus sativus $l$, was determined. Leaves presented higher percentage of moisture, protein, lipid and total carbohydrate than petals. The extracts of petals were found to contain high amount of mineral elements especially $\mathrm{Na}, \mathrm{Ca}$ and $\mathrm{N}$. Sodium was found to be the most abundant mineral with a value of $55.4 \% \mathrm{~g}$ in leaves. The leaves and petals were found to possess comparatively higher values of total flavonoids and total phenolics. The leaf extract was found to show comparatively higher antioxidant activity for 2.2-diphenyl-1picrylhydrazyl (DPPH) inhibition in comparison with the extract of petals. The leaf extracts gave higher antioxidant capacity measured with the FRAP assay. The results revealed that only leaves extract of Crocus sativus is representing a source of substances with antimicrobial activity against the studied bacteria, especially, against Listeria spp. Petals and leaves of Crocus sativus $l$, would be an important candidate in pharmaceutical formulations and play an important role in improving the human health by participating in the antioxidant defense system against free radical generation and generate in case of marketing or use of this petal and leave additional income for producers.
\end{abstract}

\section{Introduction}

Saffron (Crocus sativus L.) is a sterile triploid plant species belonging to the subfamily Rosoideae, the largest of four subfamilies currently recognized in the Iridaceae family. However, a huge amount of saffron-products with little or no commercial value are wasted when processing stigmata. Thus, about $350 \mathrm{~kg}$ of petals, $1500 \mathrm{~kg}$ of leaves, and hundreds of bulbs that due to their small size can't be ground or marketed are generated to only obtain $1 \mathrm{~kg}$ of saffron spice. Morocco was a major producer in the past, and continues to lead the saffron spice trade due to the exceptional quality of its production as well as processing and re-export spice saffron produced in other countries with extraordinary quality final product. Indeed, to obtain $1 \mathrm{~kg}$ of dry saffron, 160000 flowers are pruned, [1], this represents $300 \mathrm{~kg}$ of vegetable matter the intense honey scent. The bulbs of these flowers occur between October and May, about 1.5 tons of leaves. These two co-products, flowers and leaves, are currently unused and have been very little studied. The remaining parts of the flower are a by-product or bioresidues. Saffron spice is valued worldwide for its ability to provide color, taste, and aroma to foods and for its biomedical properties, as antitumoral and antioxidant activities [2]. Few studies about other parts of $C$. sativus flowers different to stigmas have been performed. Some flavonoids and anthocyanins have been characterized in C. sativus tepals [3-7]. Previous studies have suggested applying some parts of flowers to the food, pharmaceutical, and cosmetic industries for its antioxidant and medicinal properties [8-9]. Leaf has been used as feed for ruminants [10]. To summarize, petal and leaf constitute a source of bioactive compounds with different physiological activities and possible applications. The objective of this work was to characterize petals and leaves of Moroccan saffron regarding proximate composition, moisture, ash, protein, fat, minerals, sugars, bioactive compound, contents antibacterial activity and antioxidant capacity. The results may contribute to increased use of these petals and leaves in the generation of new products (food, pharmaceutical, and cosmetic industries) made from of saffron and generate in case of marketing or use of these petals and leaves, additional income for producers. 


\section{Material and methods}

\subsection{Sample and Collection Site}

The saffron production area which includes almost all of the product saffron in Morocco: Taliouine region and Taznakht. The petals and leaves of saffron were obtained from " Dar ZAAFARANE '(Tassousfi, Taliouine Morocco) at harvest November 2015.

\subsection{Extract preparation}

Ten grams of dried and ground petals and leaves were transferred into a flask containing $150 \mathrm{~mL}$ of the solvents (methanol 80\%, ethanol $80 \%$ and water $100 \%$ ) used for the extraction. The materials were stirred at $350 \mathrm{rpm}, 35$ ${ }^{0} \mathrm{C}$ for $24 \mathrm{~h}$ using an orbital shaker. The sample was filtered and solvent was then evaporated under vacuum using the rotary evaporator. The concentrated dried extract was transferred into a small vial and stored at $4{ }^{0} \mathrm{C}$ for further analysis.

\subsection{Proximate composition}

The moisture of freeze-dried samples and their ash content by incineration at $5500 \mathrm{C}$ were calculated according to [11]. Protein content was obtained from the total $\mathrm{N}$ content by multiplying by 6.25 , as estimated by the macro- Kjeldahl method according to [12]. Lipid content, available carbohydrates, together with energy were also deter-mined using the methods reported by [12]. The total sugar content was determined by the phenolsulfuric acid method described by [13]. The extraction of carbohydrate was made by the $80 \%$ ethanol according to the following protocol, for each variety we crushed $200 \mathrm{mg}$ sheets from each concentration in $5 \mathrm{ml}$ of $80 \%$ ethanol. Centrifuge the mixture at $5000 \mathrm{rpm}$ for $10 \mathrm{~min}$, Put $0.1 \mathrm{ml}$ of the supernatant in the test tube, add $1 \mathrm{ml}$ of $5 \%$ phenol Quickly add $5 \mathrm{ml}$ of concentrated $\mathrm{H} 2 \mathrm{~S} 04$, Place the tubes immediately to a boiling water bath for 20 min, Cool in the dark for $20 \mathrm{~min}$, Measure The optical density at $495 \mathrm{~nm}$ of using UV-Visible spectrophotometer.

\subsection{Mineral composition}

The dried leaves and petals were ground separately in a mill to pass through a 20 -mesh screen, and then $0.5 \mathrm{~g}$ of the dried plant tissues was analyzed. Nitrogen concentration in the plant tissues was determined after mineralization with sulfuric acid by "Kjeldahl method" [14], K, Ca and Na concentrations were determined by dry ashing at $400{ }^{\circ} \mathrm{C}$ for $24 \mathrm{~h}$, dissolving the ash in 1:25 HCl, and assaying the solution obtained using a flame photometer BWB-XP. The elements, including iron and zinc, were analysed by atomic absorption spectrometry in a flame air-acetylene. The measured absorption was done at a specific wavelength of $248.3 \mathrm{~nm}$.

\subsection{Total phenolic content}

The total phenolic content was measured according to the method of [15]. Sample of plant extract or standards $1.5 \mathrm{~mL}$ of $10 \%$ Folin-Ciocalteu reagent solution. All the experimental test tubes were kept at room temperature in a dark place for $5 \mathrm{~min}$. Then $1.5 \mathrm{~mL}$ of $6 \% \mathrm{Na} 2 \mathrm{CO} 3$ was added to each test tube and the mixture was kept in a dark place at room for $2 \mathrm{~h}$. Finally, the absorbance of each concentration of gallic acid was measure by UVvisible spectrophotometer at fixed wavelength $760 \mathrm{~nm}$. Methanol was used as a blank. The amounts of total phenol in the samples were calculated using a gallic acid calibration curve. The curve was prepared using 0 , $12.5,25,50,100$, and $200 \mu \mathrm{g} / \mathrm{ml}$ solutions of gallic acid in methanol. The results were expressed as mg gallic acid/g of dry plant material [15].

\subsection{Determination of total flavanoids content}

The crude extracts of petals and leaves were used for the determination of total flavonoids content. Each crude extract of petals and leaves $(4 \mathrm{mg})$ was diluted with methanol $(4 \mathrm{~mL})$. Each stock crude sample $(250 \mu \mathrm{L})$ was taken in a separate test tube. Then $125 \mu \mathrm{L}$ of water and $75 \mu \mathrm{L}$ of sodium nitrate solution were added to each test tube. The mixture was kept at room temperature for $6 \mathrm{~min}$ and then added aluminum chloride $(150 \mu \mathrm{L})$ to each test tube and kept for another $2 \mathrm{~h}$ in a dark place. All the working test tubes were diluted with sodium hydroxide $(500 \mu \mathrm{L})$ and water $(500 \mu \mathrm{L})$. The absorbance was measured by UV-visible spectrophotometer at fixed wavelength $510 \mathrm{~nm}$. Finally, total flavonoids content of the crude extract samples was calculated by using established formula [15].

\subsection{DPPH radical scavenging assay}

The antioxidant activity of the prepared crude extracts from crocus petals and leaves was measured through DPPH method according to the method of [16]. All crude extracts were dissolved in methanol and assayed in 
triplicate. The crude extracts such as methanol $80 \%(2 \mathrm{mg})$ was taken in test tube and dissolved with $10 \mathrm{~mL}$ of methanol. Five concentrations such as $12.5 \mu \mathrm{g} / \mathrm{mL}, 25 \mu \mathrm{g} / \mathrm{mL}, 50 \mu \mathrm{g} / \mathrm{mL}, 100 \mu \mathrm{g} / \mathrm{mL}$ and $200 \mu \mathrm{g} / \mathrm{mL}$ were prepared through dilution method. DPPH $(3.3 \mathrm{mg})$ was taken in a $100 \mathrm{~mL}$ volumetric flask and dissolved with methanol. Each prepared concentration $(1.5 \mathrm{~mL})$ was taken in a test tube and added $2.5 \mathrm{~mL}$ of DPPH solution. The prepared mixture was shaken gently by hand and kept in dark place for $90 \mathrm{~min}$. The absorbance of the samples was measured by using UV-visible spectrophotometer at wavelength $517 \mathrm{~nm}$. Finally, antioxidant activity of the crude extract samples was calculated by using the following formula:

$\%$ Inhibition=Absorbance standard - Absorbance crude extract /Absorbance standard $\times 100$

\subsection{Determination of reducing power}

The reducing power of samples was determined via the method of [17], with some modifications. Reducing power activity is based on the reduction of $(\mathrm{Fe} 3+)$ ferricyanide in stoichiometric excess relative to the antioxidants. Samples with different concentrations were mixed with $0.5 \mathrm{ml}$ of $0.2 \mathrm{M}$ sodium phosphate buffer $\left(\mathrm{pH}\right.$ 6.6) and $0.5 \mathrm{ml}$ of $1 \%$ potassium ferricyanide (w/v). The mixture was incubated for $20 \mathrm{~min}$ at $50^{\circ} \mathrm{C}$. After incubation, $2 \mathrm{ml}$ of $10 \% \mathrm{TCA}(\mathrm{w} / \mathrm{v})$ was added to the mixture, followed by $10 \mathrm{~min}$ of centrifugation at $650 \mathrm{rpm}$. The upper layer $(0.5 \mathrm{ml})$ was mixed with $0.5 \mathrm{ml}$ of deionized water and $0.1 \mathrm{ml}$ of $0.1 \%$ ferric chloride (w/v), and the absorbance of the resultant solution was measured at $700 \mathrm{~nm}[18]$.

\subsection{Detection of antagonistic activity}

The in vitro antimicrobial activity test was carried out by agar well diffusion assay (AWDA) (Tagg and McGiven, 1971). MHA (Mueller Hinton Agar, Biokar Diagnostic) plates were overlaid with $5 \mathrm{ml}$ of molten TSB agar $(0.75 \%$ agar) inoculated with $100 \mu \mathrm{l}$ of an overnight culture of the indicator microorganism. Wells (10 $\mathrm{mm}$ in diameter) were cut in the plates. Methanolic extracts of Crocus sativus petals and leaves were filtered and placed in wells with the appropriate quantities. Methanol was used as negative control. Plates were refrigerated $\left(4^{\circ} \mathrm{C}\right)$ for 1-2 $\mathrm{h}$ to allow the radial diffusion of the compounds contained in the wells, and then incubated at $37^{\circ} \mathrm{C}$ for $10-16 \mathrm{~h}$. The antimicrobial activity was determined by measuring the diameter of the inhibition zone around the wells.

\subsection{Statistical analysis}

Tables showing analytical values mean \pm standard deviation for three repetitions for each sample and for each analysis separation means was performed by the Tukey's test at 0,05 significance $(\mathrm{P}<0,05)$. The software used is Minitab 17.

\section{Results and discussion}

\subsection{Proximal composition}

The proximal composition of Crocus sativus petals and leaves is presented in table 1. This table shows protein, ash, moisture, lipid and carbohydrate contents. Concerning the proximal composition for Crocus sativus leaves. The leaves had higher percent of protein, lipids and total carbohydrates than those of the petals. Protein content in de leaves and petals extract was higher compared with those reported for pepper tree leaves [19] and Annona senegalensis leaves [20]. The total carbohydrate content of leaves and petals was considerably higher compared to other leafy vegetables, like Java, Cassava and Okra leaves. The protein content, ash and lipids of leaves and petals of Crocus sativus was low compared to other leafy vegetables, like Java, Cassava and Okra leaves [21].

Table 1: Comparison of proximate analysis (\%) in dried petals and leaves of Crocus sativus $l$.

\begin{tabular}{|l|l|l|l|l|l|l|}
\hline & Moisture \% & Ash \% & Protein \% & Lipid \% & Total carbohydrates \% & Caloric value kcal/g \\
\hline Petals & $92 \pm 1.11^{\text {a }}$ & $7.08 \pm 0.3$ & $6.35 \pm 0.07$ & $3 \pm 0.5$ & $71.16 \pm 1.48$ & $310.31^{\text {b } \pm 5.13}$ \\
\hline Leaves & $76.48 \pm 0.17$ & $5.36 \pm 0.4$ & $7.24 \pm 0.08$ & $6 \pm 0.4$ & $80.12 \pm 1.83$ & $349.98 \pm 3.09$ \\
\hline
\end{tabular}

${ }^{\mathrm{a}}$ Values are expressed as means $\pm \mathrm{SD}$

${ }^{\mathrm{b}}$ Energy was calculated using $4 \mathrm{kcal} / \mathrm{g}$ for proteins and available carbohydrates and $9 \mathrm{kcal} / \mathrm{g}$ for lipids.

Table 2 presents mineral content of leaves and petals of Crocus sativus. As can be observed, leaves have higher amounts of $\mathrm{Na}$ and $\mathrm{N}$ than the petals. On the other hand, petals have higher amounts of $\mathrm{Ca}$ and $\mathrm{K}$. In petals, sodium was found to be the most abundant mineral with a value of $45.85 \pm 5.44 \mathrm{ppm}$. The Fe content was significantly higher in leaves compared petals, but $\mathrm{Zn}$ content is significantly higher in petals compared leaves. Thus, the content of calcium in the petals was three times than leaves. Calcium is required by children, pregnant 
and lactating women for bones and teeth development [22]. Even though Crocus sativus leaves and petals are not typically eaten, these results are very interesting because it may be consistent with other leafy vegetable crops and would be important from a food quality standpoint.

Table 2: Mineral composition of petals and leaves of Crocus sativus.

\begin{tabular}{|l|l|l|}
\hline Minerals & Petals & Leaves \\
\hline $\mathrm{Ca}(\mathrm{ppm})$ & $39.25 \pm 1.06^{\mathrm{a}}$ & $13.85 \pm 0.21$ \\
\hline $\mathrm{Na}(\mathrm{ppm})$ & $45.85 \pm 5.44$ & $55.4 \pm 5.65$ \\
\hline $\mathrm{K}(\mathrm{ppm})$ & $23.75 \pm 2.75$ & $20.15 \pm 0.77$ \\
\hline $\mathrm{N}(\%)$ & $1.015 \pm 0.08$ & $1.15 \pm 0.013$ \\
$\mathrm{Fe}(\mathrm{mg} / \mathrm{kg})$ & $149,5 \pm 6,21$ & $985,59 \pm 10,75$ \\
$\mathrm{Zn}(\mathrm{mg} / \mathrm{kg})$ & $47,23 \pm 5,04$ & $20,59 \pm 3,53$ \\
\hline
\end{tabular}

${ }^{\mathrm{a}}$ Values are expressed as means $\pm \mathrm{SD}$

\subsection{Total phenolic and flavonoids contents}

Table 3 presents the total phenolic contents (TPC) of Crocus sativus leaves and petals. Concerning leaves, TPC for Crocus sativus leaves were higher than petals, but lower compared to the value of other leafy already published. For example, TPC for spinach and parsley were 1490 and $2390 \mathrm{mg} / 100 \mathrm{~g} \mathrm{~d}$.m., respectively [23]. In the petals, total phenolic content were lower compared to the value of fresh and spent flower of Rosa damascena Mill [24]. Regarding flavonoids, total flavonoid levels in petals were higher than leaves (table 3).

Table 3: Total yield, total phenolic and total flavonoids contents of methanolic extracts.

\begin{tabular}{|l|l|l|l|}
\hline Extract source & Total yield (\%) & ${\text { Total phenolics }(\mathbf{m g ~ G A E} / \mathbf{m g})^{\mathbf{1}}}$ Total flavanoids (mg of CE/g) $^{\mathbf{2}}$ \\
\hline Petals & $18.61^{\mathrm{a}} \pm 1.13^{3}$ & $65.34^{\mathrm{b}} \pm 1.74$ & $60.64^{\mathrm{a}} \pm 2.71$ \\
\hline Leaves & $19^{\mathrm{a}} \pm 1.39$ & $81.69^{\mathrm{a}} \pm 1.58$ & $50.64^{\mathrm{b}} \pm 1.63$ \\
\hline
\end{tabular}

${ }^{1} \mathrm{mg} \mathrm{GAE} / \mathrm{mg}$ of powder crude extract.

${ }^{2} \mathrm{mg}$ of CE/g of dry plant material.

${ }^{3}$ Mean \pm standard deviation.

\subsection{Antiradical activity}

The antioxidant capacities of leaves are higher than petals assessed by DPPH methods. The inhibition percentage among the leaves and petals crude extracts was not the same. The difference of inhibition of the crude extracts was depends on the bioactive compounds such as phenols and flavonoids presented in crude extracts [25]. The extract of the leaves shows antioxidant activity almost similar to that of $\alpha$-tocopherol and very low (figure 1).

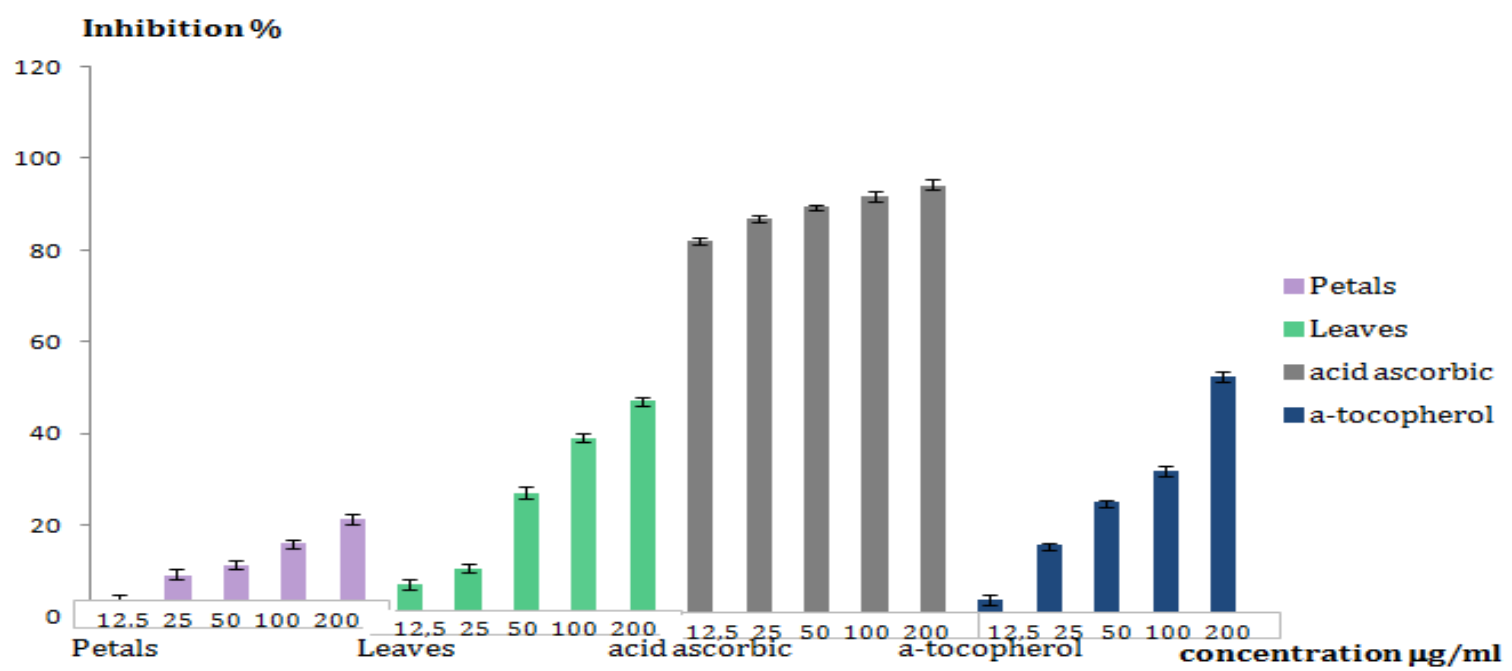

Figure 1: Antiradical activities of the methanolic extracts and synthetic antioxidants at different concentrations. 
There were differences in antioxidant capacity determined as FRAP between the extract samples as shown in (figure 2). The reducing power increased in a concentration-dependent manner in all the samples, and did not reach a saturation point in the concentration range assayed. Reducing power of petals showed a low reduction of $\mathrm{Fe}^{3+}$.

The leaf extracts gave higher antioxidant capacity; it was remarkable before that leaves extracts had exhibited more antiradical activity according to the DPPH assay (figure 1). On the other hand, acid ascorbic was the synthetic antioxidants having highest antioxidant capacity, All synthetic antioxidants exhibited higher FRAP values than those of plant extracts.

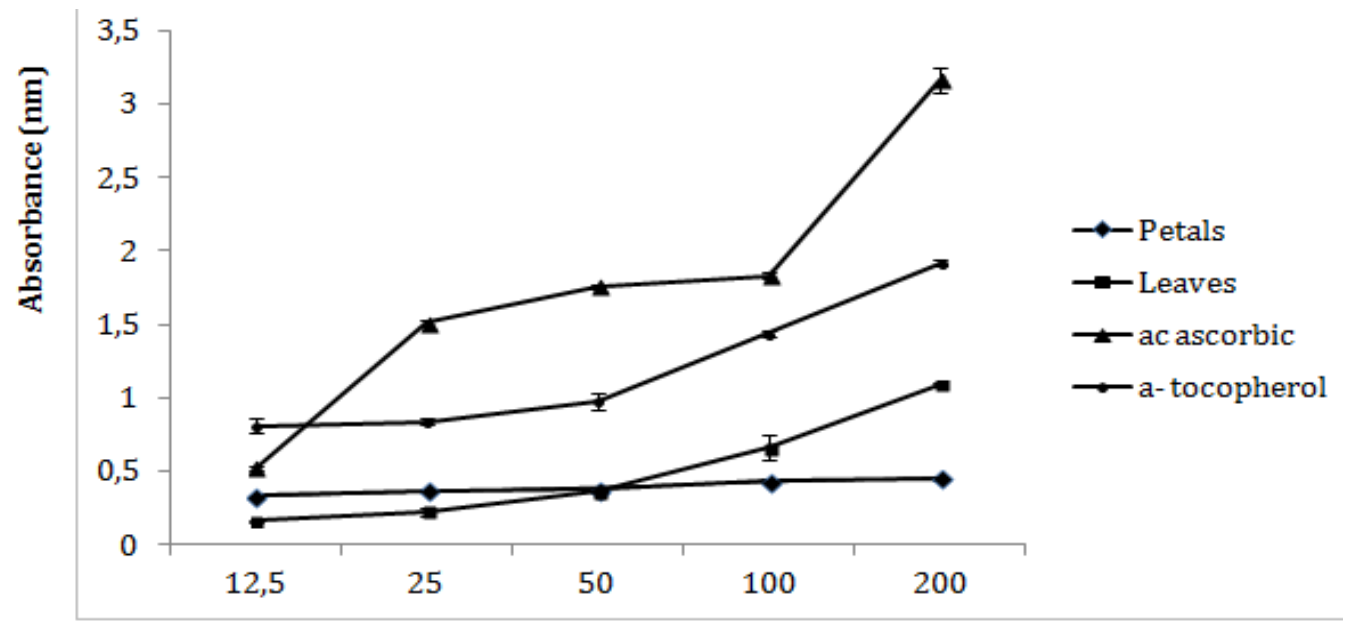

Concentration $(\mu \mathrm{g} / \mathrm{ml})$

Figure2: The total antioxidant capacities of the extracts and synthetic antioxidants determined as ferric reducing antioxidant power (FRAP).

3.3 Antibacterial activity

Table 4: Antibacterial activities of petals and leaves extracts of Moroccan Crocus sativus against bacterial pathogen

\section{$4500 \mu \mathrm{g} \quad 9000 \mu \mathrm{g} \quad 13500 \mu \mathrm{g} \quad 4500 \mu \mathrm{g} \quad 9000 \mu \mathrm{g} \quad 13500 \mu \mathrm{g}$}

Staphylococcus aureus CECT 976

Listeria spp.

Listeria innocua CECT 4030

Listeria monocytogenes CECT 4032

Bacillus subtilis DSM 6633

Proteus mirabilis

Pseudomonas aeruginosa

\begin{tabular}{llllll}
- & - & - & - & - & - \\
+ & ++ & ++ & - & - & - \\
+ & ++ & ++ & - & - & - \\
- & - & - & - & - & - \\
- & - & - & - & - & - \\
- & - & - & - & - & - \\
\hline
\end{tabular}

In the present study, the antimicrobial activity of methanolic extracts having different concentrations (4500 $\mu \mathrm{g} / \mathrm{well}, 9000 \mu \mathrm{g} / \mathrm{well}$ and $13500 \mu \mathrm{g} / \mathrm{well}$ ), was tested against six bacteria. The results revealed that only leaves extract of Crocus sativus is representing a source of substances with antimicrobial activity against the studied bacteria, especially, against Listeria spp. And, as the concentration of extracts increased, the antimicrobial activity also increased. No antimicrobial activity was observed against $S$. aureus, B. subtilis, P. aeruginosa and Proteus mirabilis. In addition no activity was observed with methanolic extract of Crocus sativus petals. The extract of crocus sativus was very effective against L. monocytogenes, and also by [26-27]. who found that some Staphylococci are resistant to the methanolic extracts of Crocus sativus leaves. Also, [28] didn't found any antibacterial activity of Crocus sativus extract when those were tested against Proteus or Staphylococcus.

\section{Conclusion}

Agro-industrial by-products are good sources of phenolic compounds, and have been explored as source of natural antioxidants. In leaves and petals, calcium, total phenolic and flavonoids was found to be the most abundant. Thus, leaves have shown excellent antioxidant capacity. Our findings suggest the potential of Crocus 
sativus 1. leaves to be utilized as a source of bioactive compounds. Moreover, the extraction of those compounds from leaves and petals should be optimized to naturally preserve foods, avoiding artificial additives and thus, contributing to the development of new functional products.

\section{References}

1. I.Kubo, I. Kinst-Hori, J. Agric. Food Chem. 47 (10) (1999) 4121-4125.

2. C. Licon, M. Carmona, S. Llorens, MI. Berruga, GL. Alonso, editor. Saffron. Functional plant science and biotechnology 4. Special Issue 2. Japan. Global Science Books. Ltd. (2010) 64-73.

3. J. Serrano-Diaz, M. Sanchez Ana, T.M. Martinez, P. Winterhalter, L. ALONSO Gonzalo, J. Food Compos. Analysis.31 (2013) 101-108.

4. JL. Garrido, Universidad Aut'onoma de Madrid. (1984).

5. R. Nørbæk, K. Brandt, JK. Nielsen, M. Ørgaard, N. Jacobsen, Biochem.Syst.Ecol. 30 (2002) 763-91.

6. S. Argento, F. Branca, L. Siracusa, T. Strano, E.M. Napoli, G. Ruberto, Acta Hort. 850 (2010) 251-60.

7. AM. S'anchez, G. Jerz, J. Serrano-D'1az, GL. Alonso, P. Winterhalter, Proceeding of the 40. Deutscher Lebensmittelchemikertag. Halle, Germany. 231 (2011) 12-14.

8. C. Ulbricht, J. Conquer, D. Costa, W. Hollands, C. Iannuzzi, R. Isaac, JK. Jordan, N. Ledesma, C. Ostroff , JM. Grimes Serrano, MD. Shaffer, M. Varghese, J. Dietary Suppl. 8 (2011) 58-114.

9. CJ. Zheng, L. Li, WH. Ma, T. Han, LP. Qin, Pharm. Biol. 49 (2011) 756-63.

10. R. Valizadeh, Proceedings of the 8th World Conference on Animal Production. vol. II. pp. (1998) 466468.

11. ISO 3632., Saffron (Crocus sativus L.). Part 1: Specification, Part 2: Test Methods. Internat. Organ. Standard. Geneva. (2011).

12. AOAC., 16th ed. Associat. Offici. Analyt. Chemists. Arlington, VA, USA, ISBN : 0935584544 (1995).

13. M. Dubois, K.A Gilles, J.K Hamilton, P.A Rebers, F.Smith, Analyt. Chem. 3 (1956) 350- 360.

14. J.M. Bremner, (Agronomy Monograph No. 9 Part 2), eds C.A Black, D.D Evans, I.L. White, L.E. Ensminger, F.E. Clark, editors. (Madison, WI: American Society of Agronomy). ISBN: 0-89118-072-9 (1965) 1149-1178.

15. A. Hamood Al-Saeedi, M. Amzad Hossain, Asian Pac. J. Trop. Dis. 5(4) (2015) 316-321.

16. M.A. Hossain, Z.H. AL-Mijizy, K. Khalifa Al-Rashdi, M.A. Weli, Q. Al-Riyami, J. of Coastal Life Medicine (2013) 1(2) 130-134.

17. M. Oyaizu, Jpn. J. Nutr. 44 (1986) 307-315.

18. S. Zilica, V. Hadzi-Taskovic Sukalovicb, D. Dodiga, V. Maksimovicb, M. Maksimovicc, Z. Basicc, J.Cereal.Scien.54 (2011) 417-424.

19. I. Chiffelle, A. Huerta, M. Celis, J.E. Araya, Indust. Crops. Products. 43(0) (2013) 523-528.

20. M. Tijjani, F. Abdurahaman, Y. Abba, M. Idris , B. Baburo , G. Mala, M. Dungus, B. Aji, K. Abubakar, Pharmaceut. Scien. Innovat. 2(1) (2013)

21. M.M. Raimi, A.M. Oyekanmi, A.G. Farombi, Scientific Research Journal, II(IV). (2014) 30-34.

22. A. Sodamode, O. Bolaji, O. Adeboye, IOSR J. Applied. Chem (IOSR-JAC). 4(6) (2013) 47-51.

23. H. Karaca, Y.S. Velioglu, Postharvest. Biol. Techn. 88 (2014) 46-53.

24. G. Nilgun, H. Baydar, Indust. Crops. Prod. 41(2013) 375- 380.

25. N. Wu, K. Fu, YJ. Fu, YG. Zu, FR. Chang, YH. Chen, XL. Liu, Y. Kong, W. Liu, CB.Gu, Molecules. 14 (2009) 1032-1043.

26. G. Okmen, S. Kardas, D. Bayrak, A.Arslan, H. Cakar, j. Pharm. Parmaceut.sciences. 5(3) (2016) 146156.

27. E.F Obasola, O.E. Cajethan, A.O. Abolade, A.O. Adeniyi, AUJ Techn. 13(3) (2010)165-169.

28. E.H. Soureshjan, M. Heidari, Electronic J. Biol. 10(3) (2014) 64-67.

(2018) ; http://www.jmaterenvironsci.com 